\title{
Química Sem Dor
}

$>$

Marta Piñeiro

mpineiro@qui.uc.pt

Quando pensamos na relação entre a química e a saúde lembramo-nos imediatamente dos fármacos, das vacinas, e até dos desinfetantes, e reconhecemos o importante papel que a química teve, e tem, no aumento da esperança de vida durante o último século. Mas, há uma parte da relação entre a química e a medicina de que habitualmente não nos lembramos, os anestésicos. 0 desenvolvimento da anestesia, termo proveniente do grego anaisthesía, que significa "insensibilidade" ou "ausência de sensação", é fulcral no desenvolvimento da medicina moderna. A anestesia é um procedimento médico que diminui a capacidade do paciente sentir dor durante a intervenção médica, habitualmente cirúrgica, o que tem permitido realizar procedimentos que de outra forma seriam insuportáveis, prolongando a vida. O primeiro químico utilizado para a eliminação da dor foi o óxido nitroso ( $\left.\mathrm{N}_{2} \mathrm{O}\right)$, também conhecido como gás hilariante. $\mathrm{O}$ éter dietílico $\left(\left(\mathrm{CH}_{3} \mathrm{CH}_{2}\right)_{2} \mathrm{O}\right)$ e mesmo o clorofórmio $\left(\mathrm{CHCl}_{3}\right)$ foram utilizados como anestésicos gerais administrados por inalação, durante muitos anos.

A investigação nesta área levou ao desenvolvimento de anestésicos para administração por inalação e administração intravenosa. Os anestésicos administrados por inalação são compostos halogenados, tal como o isoflurano, o halotano ou o sevoflurano. Evidentemente, são moléculas de baixo peso molecular e voláteis; os que se encontram no estado líquido à temperatura ambiente são volatilizados para administração como substância pura na forma gasosa. Já os anestésicos administrados por via intravenosa, como o propofol, são líquidos à temperatura ambiente e administrados em emulsão, habitualmente, com óleo de soja, lecitina de ovo e glicerol.

Todos estes anestésicos são preparados por síntese laboratorial. Muita Química, sem dor!

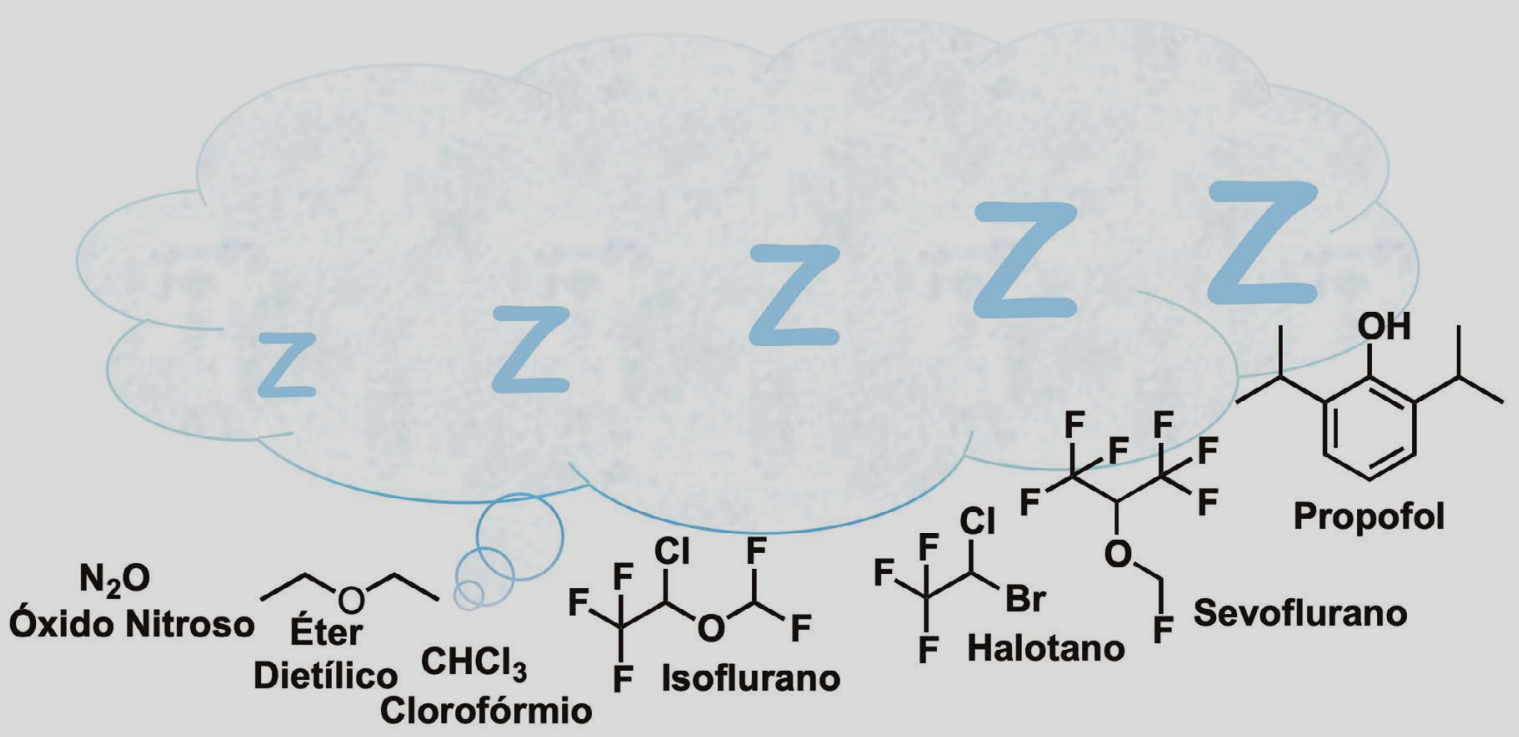

\section{Saiba mais em:}

Chemistry Is Life.com, The Chemistry of General Anesthesia: chemistryislife.com/ the-chemistry-of-general-anesthesia (acedido em 21/12/2020). Segredos da Luz e da Matéria: A química da anestesia: sites.google.com/site/ segredosluzmateria/a-quimica-da-anestesia (acedido em 21/12/2020). 